BEATA SIWEK

\title{
BIAŁORUTENISTYKA POLSKA. HISTORIA - STAN OBECNY - PERSPEKTYWY ROZWOJU
}

Przewodni temat zeszytu 7 Roczników Humanistycznych za rok 2021 „Slawistyka - historia i perspektywy” - zachęca do refleksji nad miejscem, rolą, osiągnięciami i perspektywami badań białorutenistycznych w polskiej myśli slawistycznej. Wyraźny wzrost zainteresowania kulturą, historią, literaturą i językiem Białorusinów wiąże się nieodłącznie z przełomowymi wydarzeniami politycznymi i społecznymi na Białorusi: najpierw z XIXwiecznymi działaniami powstańczymi (powstanie listopadowe, powstanie styczniowe), ruchami narodowymi początku XX wieku, białoruskim ruchem wydawniczym (działalność wileńskiej „Naszej Niwy”, Białoruskiego Towarzystwa Wydawniczego), dalej z okresem kształtowania się niezależnego państwa białoruskiego - Białoruskiej Republiki Ludowej w 1918 r. i okresem białorutenizacji, określanej nierzadko również „białorusizacją” (Głogowska, Białoruś 1914-1929 10), która rozpoczęła się na początku lat 20. XX wieku, a została wstrzymana już u schyłku lat 20. oraz w latach 30 . przez politykę państwa radzieckiego (stalinowskie „czystki” wśród białoruskiej inteligencji i twórców kultury), które na wiele lat poważnie ograniczyło Białoruś pod względem językowym i kulturowym, z narodzinami powojennej opozycji białoruskiej, tragedią czarnobylską, wreszcie $\mathrm{z}$ rozpadem Związku Radzieckiego w 1991 r., ogłoszeniem suwerennej i niezależnej Białorusi, która obecnie zmuszona jest walczyć o narodową i polityczną tożsamość, własną kulturę i język.

Początki polskich badań filologicznych dotyczących języka i kultury Białorusinów sięgają XIX wieku. Jednym z prekursorów językoznawczych

Dr hab. Beata SiweK, prof. KUL - Katolicki Uniwersytet Lubelski Jana Pawła II, Wydział Nauk Humanistycznych, Instytut Literaturoznawstwa, Katedra Literatury Rosyjskiej, Ukraińskiej i Białoruskiej, adres do korespondencji: Al. Racławickie 14, 20-950 Lublin; e-mail: beata.siwek@kul.pl; ORCID: https://orcid.org/0000-0002-0742-3431. 
badań białorutenistycznych w Polsce był Samuel Bogumił Linde, który pod wpływem prac rosyjskich i czeskich badaczy nad spuścizną wschodniosłowiańską, w szczególności monografii Wasyla Sopikowa, opublikowanej w Sankt Petersburgu w 1813 r. - Onыт российской библиографии, zainteresował się językiem Statutu litewskiego i przedmowami do Biblii Franciszka Skaryny. To zainteresowanie zaowocowało szeregiem prac naukowych, ukierunkowanych na badanie osobliwości językowych najstarszych zabytków literackich na ziemiach białoruskich. Poznański językoznawca Tadeusz Lewaszkiewicz pisał na ten temat:

Linde na podstawie próbek tekstów pokazał odrębność białoruskiego, cerkiewnosłowiańskiego i polskiego. Świadczy to dobrze o jego filologicznej metodzie ukazywania różnic międzyjęzykowych. Nikt przed Lindem nie opowiedział się tak zdecydowanie za częściowo białoruskim charakterem języka Statutu litewskiego. Jest to trwała zasługa leksykografa dla filologii białoruskiej i wschodniosłowiańskiej. Za istotne należy także uznać zwrócenie uwagi na wyraźne różnice między cerkiewnosłowiańskim, białoruskim i rosyjskim. (101)

Dziewiętnastego wieku sięgają także zainteresowania polskich badaczyliteraturoznawców literaturą białoruską. Fakt ten wiąże się zapewne z obecnym w polskiej literaturze romantycznej zwrotem do folkloru białoruskiego, koncentracją na roli białoruskiej poezji ludowej, formowaniem się tzw. „szkoły białoruskiej” w literaturze polskiej. W tym czasie ukazało się kilka ważnych prac literaturoznawczych, m.in. monografia Aleksandra Rypińskiego Białoruś, kilka stów o poezji prostego ludu tej naszej polskiej prowincji; o jego muzyce, śpiewie i tańcach etc. (1840), wstęp Jana Czeczota do jego Piosnek wieśniaczych znad Niemna i Dźwiny (1837), artykuł Jana Barszczewskiego „Szkic Północnej Białorusi”, zamieszczony we wstępie do poematu Szlachcic Zawalnia czyli Biatoruś w fantastycznych opowiadaniach (1843), artykuł Kazimierza Bujnickiego „Piosnki gminne białoruskie" (1843), opublikowany w trzecim tomie pisma Rubon, artykuł Ignacego Chrapowickiego „Rzut oka na poezję ludu biało-ruskiego”, zamieszczony w piątym numerze tegoż pisma za 1845 rok czy wreszcie znany artykuł Romualda Podbereskiego „Białoruś i Jan Barszczewski”, opublikowany we wspomnianym już poemacie Szlachcic Zawalnia Jana Barszczewskiego (Jackiewicz 117-119). Badania etnograficzne na Białorusi prowadzili także w tym okresie Maria Czarnowska, Zorian Dołęga-Chodakowski (Adam Czarnocki), Ignacy Szydłowski, Romuald Zienkiewicz, Eustachy Tyszkiewicz i Michał Fedorowski. Interesująco kwestie te przedstawił Mścisław Olech- 
nowicz w monografii Polscy badacze folkloru i języka białoruskiego w XIX wieku, wydanej w Łodzi w $1986 \mathrm{r}$.

Początek wieku XX przyniósł jeszcze kilka znaczących publikacji białorutenistycznych o charakterze historycznoliterackim. Mowa tu o znanym Zarysie literatury białoruskiej Bohdana Żyranika, wydanym w Warszawie w 1921 r., Krótkim zarysie literatury białoruskiej Maksima Hareckiego, wydanym w Wilnie w 1921 r., Zarysie dziejów literatur i języków literackich słowiańskich Aleksandra Brücknera i Tadeusza Lehra-Spławińskiego (Lwów 1929), szkicu przybliżającym literaturę białoruską, autorstwa jedynego w Polsce międzywojennej historyka literatur wschodniosłowiańskich - Józefa Gołąbka, zamieszczonym w czwartym tomie Wielkiej Literatury Powszech$n e j$, a opublikowanym $\mathrm{w}$ Warszawie $\mathrm{w} 1933$ r., oraz wydanej trzy lata później, również w Warszawie, monografii Marii Rudzińskiej-Froelichowej Uwagi nad literatura białoruska (Kondratiuk 242).

W okresie międzywojennym ważnym ośrodkiem naukowym był Uniwersytet Wileński, na którym prowadzono badania z zakresu białoruskiego języka, literatury, etnografii i historii, a w ofercie dydaktycznej można było znaleźć także przedmioty białorutenistyczne:

Niestety długo istniały problemy z lektoratem języka białoruskiego. Pierwszy raz, na rok, pojawił się on w roku akademickim 1920/21, prowadzącym był zaś Marian Massonius. Stały lektorat zaczęto prowadzić dopiero po dziesięciu latach, od roku akademickiego 1930/31. Prowadził je Białorusin dr Jan (Janka) Stankiewicz. Od roku akademickiego 1938/1939 prowadził też zajęcia z zakresu nowszej literatury białoruskiej. W trakcie swojej pracy na USB Stankiewicz przygotował także kilka prac językoznawczych poświęconych na przykład historii języka białoruskiego. Z kolei w pierwszym roku istnienia uczelni Feliks Koneczny prowadził zajęcia „Przegląd dziejów Litwy i Białorusi”. Z kolei w roku 1924 oraz także później, Cezaria Baudouin de Courtenay-Ehrenkreutzowa dawała wykłady z zakresu etnografii Białorusinów. (Srebrakowski 91)

Z Uniwersytetem Wileńskim byli związani także prawnicy i historycy, prowadzący badania nad historią ustroju i prawa sądowego Wielkiego Księstwa Litewskiego: Stefan Ehrenkreutz, Jan Adamus, Seweryn Wysłouch, Alina Wawrzyńczykowa, Henryk Łowmiański i Stanisław Franciszek Zajączkowski (Srebrakowski 91).

Do ważnych publikacji wileńskich badaczy należy zaliczyć bogato ilustrowaną dwutomową monografię wieloautorską Wilno i ziemia wileńska: zarys monograficzny (t. 1 - 1930, t. 2 - 1937), która ukazała się nakładem Wydawnictwa Wojewódzkiego Komitetu Regionalnego, monografie Seweryna 
Wysłoucha Stosunki narodowościowe na terenie województw wschodnich (1939-1940) ${ }^{1}$, Świadomość narodowa ludności prawosławnej zamieszkujacej wschodnie i pótnocno-wschodnie powiaty Wileńszczyzny (1939) oraz Пadручны беларуска-польскі слоуннік Bolesława Druckiego-Podbereskiego, który ukazał się w Wydawnictwie Wileńskim B. Kleckina w 1929 r. pod redakcją Wincentego Hryszkiewicza, członka Białoruskiego Towarzystwa Naukowego w Wilnie. W „Przedmowie" ${ }^{2}$ do słownika Druckiego-Podbereskiego czytamy:

Nasz wysiłek skierowany był na to, by dać słownik żywego białoruskiego języka, którym mówi nasz naród i w jakim pisane są białoruskie książki i pisma. Niewątpliwie w naszym słowniku, oprócz czysto białoruskich słów, znajdują się rusycyzmy i polonizmy, które weszły w skład żywego ludowego języka, a również znajdą się i nowotwory białoruskich filologów: J. Stankiewicza, M. Hareckiego, Łastowskiego i inn., które są używane w białoruskiej literaturze. Wiemy dobrze, iż nasz słownik ma sporo stron ujemnych, jak w stosunku do opracowania jego, tak i do zewnętrznego wykonania pracy-druku. Niedostatki w opracowaniu pochodzą nie tylko z naszej winy ile ze względu na brak odpowiednich materjałów. Przystępując do opracowania słownika mieliśmy pod rękoma tylko: „Mały Białorusko-rosyjski słownik” M. Hareckiego i „Rosyjsko-krywicki (białoruski) słownik" Łastowskiego. (12)

Wzrost zainteresowania badaniami białorutenistycznymi przypadł na okres powojenny, choć - co warto zaznaczyć - zdecydowanie częściej dotyczyły one zagadnień językoznawczych i kulturologicznych, rzadziej - problematyki historycznej, o czym pisze Helena Głogowska w artykule „Stan badań nad historią Białorusi XX w. w Polsce":

Badania nad historią Białorusi XX w. na ogół nie mieściły się w programach środowisk naukowych w Polsce. Były one przedmiotem dociekań pojedynczych uczonych podejmujących opracowanie poszczególnych tematów z własnej inicjatywy. [...] W okresie powojennym najcenniejsze artykuły i rozprawy wyszły spod pióra Aleksandry Bergman, Aleksego Derugi i Jerzego Tomaszewskiego. (97-98)

Spośród nich należy wymienić monografie Polityka wschodnia Polski wobec ziem Litwy, Białorusi i Ukrainy, $1918-1919$ (1969) A. Derugi, Rzecz o Bronistawie Taraszkiewiczu (1977) oraz Sprawy białoruskie w II Rzeczy-

\footnotetext{
${ }^{1}$ W 2013 r. Studium Europy Wschodniej Uniwersytetu Warszawskiego opublikowało reedycję tej monografii.

${ }^{2}$ Przedmowa do słownika ma trzy warianty: dwa warianty białoruskojęzyczne (pierwszy pisany cyrylicą, drugi łacinką) i jeden wariant polskojęzyczny.
} 
pospolitej (1984) A. Bergman czy Studia polsko-litewsko-białoruskie pod red. J. Tomaszewskiego, E. Smułkowej, H. Majeckiego (1988) i Mniejszości narodowe w Polsce XX wieku (1991) J. Tomaszewskiego. W 1979 r. ukazała się ponadto Historia Białorusi Marcelego Kosmana.

W tym czasie głównym ośrodkiem rozwoju badań białorutenistycznych w Polsce była Pracownia Filologii Białoruskiej utworzona w Instytucie Polsko-Radzieckim w 1953 r., na której czele stanęła prof. Antonina Obrębska-Jabłońska. W grudniu 1957 r. Pracownia ta została włączona do Zakładu Słowianoznawstwa Polskiej Akademii Nauk, przemianowanego w 1977 r. w Instytut Słowianoznawstwa, a obecnie w Instytut Slawistyki (Smułkowa 283). 1 września 1947 r. Antonina Obrębska-Jabłońska została zatrudniona na stanowisku docenta w Katedrze Slawistyki Uniwersytetu Warszawskiego, a w latach 1950-1952 kierowała Sekcją Rusycystyczną Instytutu Slawistyki tegoż uniwersytetu. Badacze-językoznawcy zatrudnieni w Pracowni Filologii Białoruskiej Instytutu Słowianoznawstwa Polskiej Akademii Nauk opracowali i wydali drukiem dziesięciotomowy Atlas gwar wschodniosłowiańskich Białostocczyzny (1980-2012) oraz naukowo opracowali trzy tomy materiałów folklorystycznych Michała Federowskiego Lud Białoruski (t. 5-7, 1958, 1960, 1969). Kiedy - decyzją Ministerstwa Nauki i Szkolnictwa Wyższego w 1956 r. - wydano zgodę na utworzenie studiów białorutenistycznych i powołanie do życia Katedry Filologii Białoruskiej w Uniwersytecie Warszawskim prof. A. Obrębska-Jabłońska objęła funkcję jej pierwszego kierownika. To z tą jednostką naukowo-dydaktyczną związali na długie lata swoje losy naukowe prof. Elżbieta Smułkowa, uczennica prof. Haliny Turskiej (która w okresie międzywojennym prowadziła badania językoznawcze w Wilnie), oraz prof. Aleksander Barszczewski - późniejsi kierownicy Katedry. O roli i specyfice warszawskich studiów prof. Smułkowa pisała:

Organizacja nowej jednostki naukowo-dydaktycznej przy braku odpowiednio wykształconej kadry wymagała nie lada pomysłowości i wysiłku. W pierwszych latach studiów wspomagali nas wykładowcy z Białorusi, znani lingwiści, Mikołaj Biryła i Alaksandr Żurauski oraz historycy literatury Władzimier Tarasau i Marian Łazaruk [...]. Atrakcją warszawskich studiów białorutenistycznych były zainicjowane przez nią praktyki dialektologiczne na terenie gwar wschodniosłowiańskich wschodniej Białostocczyzny i regularne, coroczne wyjazdy kolejnych grup na wymienną miesięczną, krajoznawczą praktykę studencką, organizowaną we współpracy z Białoruskim Uniwersytetem Państwowym w Mińsku. W wyjazdach tych profesor początkowo uczestniczyła osobiście, wciągając młodych współpracowników i studentów w tajniki prowadzenia pracy terenowej z miejscowymi ludźmi 
i nawiązując dobre naukowe kontakty personalne na Białorusi, które owocowały w dalszym kształceniu i gromadzeniu materiałów do prac naukowych. (Smułkowa 284)

Warto dodać, że prof. A. Obrębska-Jabłońska, współpracująca przez wiele lat z prof. E. Smułkową, kierowała wieloma znaczącymi zespołowymi projektami badawczymi. Do jej najważniejszych inicjatyw naukowo-wydawniczych należą: opracowanie i publikacja w 1962 r. Podręcznego słownika polsko-białoruskiego (red. A. Obrębska-Jabłońska, M. Biryła), wydanie w 2012 r. Stownika biatorusko-polskiego pod redakcją Teresy Chylak-Schreder, Jadwigi Głuszkowskiej-Babickiej i Teresy Jasińskiej-Sochy oraz zebranie i opracowanie nazw terenowych północno-wschodniej Polski wydanych pod redakcją E. Smułkowej w latach 1992-1995 - Stownik nazw terenowych pótnocno-wschodniej Polski, przy współpracy N. Barszczewskiej, J. Głuszkowskiej i T. Jasińskiej-Sochy.

Z Instytutem Słowianoznawstwa PAN jest związana także działalność naukowa kilku innych badaczy-slawistów: prof. Bazylego Białokozowicza, autora licznych artykułów poświęconych związkom twórczości Adama Mickiewicza z Białorusią, literackiej spuściźnie Franciszka Skaryny, twórczości prozatorskiej i eseistycznej Sokrata Janowicza, prac biobliograficznych dotyczących znanych białoruskich literaturoznawców, m.in Adama Maldzisa, Uładzimira Kazbiaruka, Swietłany Musijenko i Walanciny Hapawaj (Stochel 54-55); historyka i działacza białoruskiej mniejszości narodowej w Polsce, dr. Jerzego Turonka, autora książek Wacław Iwanowski i odrodzenie Białorusi (1992), Białoruś pod okupacja niemiecka (1993), Ksiażka białoruska w II Rzeczypospolitej 1921-1939 (2003), Białoruski ruch chrześcijański XX wieku: stownik biograficzno-bibliograficzny (wraz z dr. hab. Jerzym Garbińskim, 2003); dr hab. Anny Engelking, której zainteresowania badawcze oscylują wokół antropologii wsi białoruskiej, problematyki pogranicza polsko-białorusko-litewskiego i Polesia białorusko-ukraińskiego (tym zagadnieniom zostały poświęcone monografie autorskie Klątwa. Rzecz o ludowej magii stowa (2000) oraz Kołchoźnicy. Antropologiczne studium tożsamości wsi białoruskiej przełomu XX i XXI wieku (2012), za którą autorka otrzymała w 2016 r. Nagrodę Międzynarodowego Kongresu Badaczy Białorusi w kategorii: najlepsza polska monografia dotycząca Białorusi w latach 2011-2015) oraz dr. Mirosława Jankowiaka, autora monografii Gwary białoruskie na Łotwie $w$ rejonie krastawskim. Studium socjolingwistyczne (2009), a także kilkudziesięciu artykułów poświęconych dialekto- 
logii białoruskiej, zagadnieniu pogranicza językowego, wybranym problemom socjolingwistyki.

Drugi kierownik warszawskiej katedry białorutenistycznej (1971-1975) prof. Elżbieta Smułkowa, najwybitniejsza polska badaczka w zakresie języka i dialektów białoruskich, słowiańskiego językoznawstwa porównawczego, problematyki socjo-etnolingwistycznej, w dużej mierze kontynuowała wyznaczony przez prof. A. Obrębską-Jabłońską kierunek badań, poszerzając konsekwentnie pole naukowych eksploracji. Profesor Smułkowa jest autorką ponad 160 publikacji naukowych, m.in. monografii Studia nad akcentem języka białoruskiego (1978), Język i kultura białoruska w kontakcie z sasiadami (2001), Białoruś i pogranicza. Studia o języku i społeczeństwie (2002) oraz artykułów Le bilinguisme à la Bielorusse, Identity and Toleration in Byelorussia, Ksztatt wspótistnienia na polsko-białorusko-litewskim pograniczu językowym, Pogranicze językowe jako przedmiot współczesnej dialektologii, Badanie pograniczy językowych - uwagi metodologiczne, Wielojęzyczność czy tendencja do unifikacji? Na przykładzie brasławskiego fragmentu pogranicza polsko-białorusko-litewskiego, Integracja języków na pograniczu biatorusko-polsko-litewskim $i$ jej konsekwencje dla teorii zapożyczeń.

Naukowe, dydaktyczne i organizacyjne osiągnięcia prof. Smułkowej zostały docenione zarówno przez władze rodzimego uniwersytetu, jak i za granicą. Profesor E. Smułkowa w latach 1978-1981 pełniła funkcję prodziekana ds. studenckich Wydziału Rusycystyki, Slawistyki i Lingwistyki stosowanej Uniwersytetu Warszawskiego, a w latach 1987-1990 - funkcję prodziekana ds. naukowych Wydziału Polonistyki tegoż uniwersytetu. Od 1991 do 1992 r. pełniła ponadto funkcję Konsula Generalnego RP, a w latach 1992-1995 Ambasadora RP na Białorusi. W 2005 r. została odznaczona przez Prezydenta RP Aleksandra Kwaśniewskiego Krzyżem Kawalerskim Orderu Odrodzenia Polski.

Z warszawską białorutenistyką był związany przez wiele lat $\mathrm{dr}$ hab. Mikołaj Timoszuk, kierownik Katedry w latach 2004-2009, zajmujący się rosyjską i białoruską leksykologią i leksykografią. Jego liczne publikacje, m.in. O języku białoruskich przektadów Ewangelii w Ameryce Pótnocnej, Księga Rodzaju w przekładach na wspótczesny język białoruski oraz Wspótczesne białoruskie stownictwo sakralne w przekładach Pisma Świętego stanowią niezwykle znaczące osiągnięcie w zakresie badań nad współczesnym białoruskim językiem religijnym. 
Językoznawczy kierunek badań białorutenistycznych w Uniwersytecie Warszawskim rozwija także dr hab. Nina Barszczewska - kierownik Katedry Białorutenistyki w latach 2009-2014 i 2016-2018. W obszarze jej zainteresowań naukowych pozostają: historia języka białoruskiego, język białoruskiej emigracji, zagadnienie pogranicza językowego, onomastyka oraz dialektologia. W latach 1982-2019 dr hab. N. Barszczewska opublikowała 11 książek (w tej liczbie książki współautorskie, redagowane i współredagowane), ponad 100 artykułów naukowych, recenzji i sprawozdań, ponad 500 materiałów medialnych. Poza wymienionymi wyżej publikacjami słownikowymi dr hab. Nina Barszczewska jest autorką monografii Беларуская эміграиьля - абаронца роднае мовы (2004) oraz Dialektologia białoruska (2012, we współautorstwie z dr. Mirosławem Jankowiakiem). Monografia ta stanowi pierwsze spójne i całościowe omówienie gwar białoruskich jako odzwierciedlenia osadnictwa plemion białoruskich oraz procesów migracyjnych Słowian i Bałtów, zarys historii badań dialektów białoruskich oraz analizę i podział gwar (gwary białoruskie na terenie Białorusi, poza granicami Białorusi, nowe tendencje w gwarach białoruskich, udział dialektów białoruskich w kształtowaniu się i rozwoju współczesnego języka białoruskiego, nowe tendencje w gwarach białoruskich). Do pracy zostały dołączone mapy, teksty gwarowe oraz słowniczek terminów językoznawczych odnoszących się do białoruskiego obszaru językowego. Ważną inicjatywą naukową dr hab. Niny Barszczewskiej było także przygotowanie i realizacja projektu naukowego, którego głównym celem było zbadanie polsko-wschodniosłowiańskiej interferencji językowej i historyczno-kulturowej, analiza zachowania społeczności dwujęzycznej na styku kultur i tradycji, realizowanego w ramach grantu Narodowego Programu Rozwoju Humanistyki w latach 2012-2016, wraz z innymi pracownikami Katedry (Barszczewska, Kulturowo-językowe dziedzictwo Podlasia 267). Rezultatem podjętych badań była publikacja w 2016 r. trzytomowej monografii pt. Kulturowo-językowe dziedzictwo Podlasia.

$\mathrm{W}$ zakresie prac badawczych prowadzonych w Katedrze znajduje się także problematyka glottodydaktyczna. Spośród publikacji poświęconych tym zagadnieniom warto wyróżnić monografie dr hab. Radosława Kalety Polsko-białoruska lapsologia glottodydaktyczna (2015) oraz Błędologia w glottodydaktyce białorutenistycznej (2018).

Duży wkład w rozwój badań językoznawczych w tym ośrodku wnieśli także dr Jadwiga Głuszkowska-Babicka, dr Teresa Jasińska-Socha, dr Teresa Chylak-Schroeder oraz dr Volha Tratsiak. 
Warszawski ośrodek białorutenistyczny może poszczycić się także sporymi osiągnięciami w dziedzinie badań literaturoznawczych. Najważniejsze należy wiązać z naukową aktywnością prof. Aleksandra Barszczewskiego, który kierował Katedrą Białorutenistyki w latach 1975-2004 i miał nieoceniony wpływ na rozwój kadry naukowo-dydaktycznej tej jednostki. Naukowy dorobek prof. Barszczewskiego zaskakuje tematyczną różnorodnością, doskonałą znajomością kulturowo-literackich kontekstów, otwartością na nowe metodologie i perspektywy badawcze. Na naukową spuściznę prof. Aleksandra Barszczewskiego składają się trzy monografie autorskie: Białoruska obrzędowość i folklor wschodniej Białostocczyzny (1990), Tвориь беларускага літаратурнага руху у Польшчь. 1958-1998 (2001) oraz Беларуская эміграџыйная пісьмовасиь (2004), ponad sto artykułów, studiów i prac krytycznoliterackich, cztery podręczniki i skrypty (m.in. Historia literatury białoruskiej. Folklor), ponad dwadzieścia publikacji przekładowych i literackich, kilkaset prac popularnonaukowych, drukowanych cyklicznie na łamach wydawanego w Białymstoku od 1958 r. białoruskiego tygodnika „Niwa”, m.in. cykle Беларуская літаратура, Беларускі фальклор, Радзіма-Родина, a także kilkaset esejów emitowanych na antenie Redakcji Białoruskiej Radia Polonia: Беларускі літаратурны рух у пасляваеннай Польшчы, Беларуская эміграџыйная пісьмовасиь (Siwek, Profesor Aleksander Barszczewski 212).

Aleksander Barszczewski (literacki pseudonim Aleś Barski), to także tłumacz i poeta, autor zbiorów poetyckich Белавежскія матывы (1959), Жнівень слоў (1967), Мой бераг (1976), Блізкасиь далёкага (1984), Лірычны пульс (1987), Выбраныя творы (2011).

Literaturoznawcze osiągnięcia warszawskiej białorutenistyki są związane także z działalnością naukową prof. Mikołaja Chaustowicza, wybitnego znawcy białoruskiej literatury dziewiętnastowiecznej, który jest pracownikiem Katedry Białorutenistyki od 2005 r., autora naukowych monografii На парозе забытае святыні. Творчасиь Яна Баршчэускага (2002), Мастаикі метад Яна Баршчэусккага (2003), Айчына здалёку і зблізку. Ігначь Яикоусккі і Аляксандр Рыпінскі (2006), Жыииё і творчасиь Рамуальда Падбярэскага (2008), Шляхам да беларускасиі. Нарысы, артыкулы, эсэ (2010), wielotomowych edycji krytycznych - Даследаванні і матэрыялы: Літаратура Беларусі XVIII - ХIX стагоддзяу (2014, 2016, 2018), Даследаванні і матэрыяль: Літаратура Беларусі XIX - пачатку XX стагоддзя (2017, 2019), Даследаванні і матэрыяль: Літаратура Беларусі ХІХ стагоддзя (2020) oraz antologii - Беларуская літаратура. 
Хрэстаматыя. Частка першая (другая палова XVIII - першая палова ХІХ стст., 2006), Беларуская літаратура. Хрэстаматыя. Частка другая (другая палова XIX cm, 2006). Spośród prac młodszych badaczy literaturoznawców warto wymienić monografie Białoruski postmodernizm. Liryka pokolenia Bum-Bam-Litu (2009) dr Katarzyny Bortnowskiej ${ }^{3}$ oraz Białoruska literatura łagrowa (2019) dr Katarzyny Drozd.

W latach 1978-2014 z warszawską białorutenistyką była związana także dr Nadzieja Panasiuk, autorka ponad 40 artykułów naukowych poświęconych białorusko-polskim związkom literackim, satyrze w literaturze białoruskiej, polskim przekładom literatury białoruskiej (m.in. Польска-беларускі кантэкст паэзіі Надзеі Apтымовіч, Franciszek Bahuszewicz i jego zwiazki z Polska, Polskie przektady prozy Jakuba Kolasa, O przekładzie frazeologizmów $w$ polskich tłumaczeniach wspótczesnej literatury biatoruskiej, Satyra wobec białoruskiej rzeczywistości politycznej, Satyra polityczna w białoruskiej literaturze współczesnej).

Ważną inicjatywą pracowników Katedry Białorutenistyki UW było zapoczątkowanie działalności czasopisma naukowego Acta Albaruthenica (pod redakcją Mikołaja Chaustowicza i Mikołaja Timoszuka), którego pierwszy numer ukazał się w 1998 r. i który po dziś dzień stanowi ważne forum prezentacji studiów, rozszerzonych analiz, wymiany myśli i opinii dotyczących białoruskiego języka, historii, kultury i literatury.

Znaczący wzrost zainteresowania badaniami i studiami białorutenistycznymi w Polsce przypadł na schyłek lat 80 . i początek lat 90 . XX wieku - okres transformacji ustrojowej, czas odradzania się białoruskiej myśli narodowej, języka, kultury.

Ważny wkład w rozwój badań białorutenistycznych w tym okresie wnieśli wykładowcy akademiccy związani z dwoma lubelskimi ośrodkami uniwersyteckimi - Katolickim Uniwersytetem Lubelskim Jana Pawła II oraz Uniwersytetem Marii Curie-Skłodowskiej.

Badania naukowe prowadzone w Instytucie Filologii Słowiańskiej KUL (jako jednostka organizacyjna istniał do 30 września 2019 r., najpierw jako Sekcja Filologii Słowiańskiej) obejmowały folklor rosyjski, literaturę i kulturę staroruską, literaturę rosyjską wieku XVII i XVIII, rosyjską literaturę i myśl religijno-filozoficzną XIX w., współczesną literaturę rosyjską, dzieje słowianoznawstwa rusycystycznego i ukrainistycznego, wpływ chrześcijaństwa na kulturę narodów wschodniosłowiańskich, komparatystykę polsko-wschodniosłowiańską, czy wreszcie translatologię. W tak szeroko zakro-

\footnotetext{
${ }^{3}$ Doktor K. Bortnowska pracowała w Katedrze Białorutenistyki UW do 31 grudnia 2015 r.
} 
jonym obszarze badawczym nie zabrakło miejsca na problematykę białorutenistyczną. To tu, dzięki inicjatywie prof. Ryszarda Łużnego, który z Katolickim Uniwersytetem Lubelskim był związany od 1982 r., najpierw jako kierownik Międzywydziałowego Zakładu Badań nad Kulturą Bizantyńsko-Słowiańską, a od 1989 r. jako kierownik Sekcji Filologii Słowiańskiej, na Wydziale Nauk Humanistycznych uruchomione zostały studia slawistyczne. Już od pierwszego roku akademickiego, tj. od 1989/90 studia były prowadzone w trzech specjalnościach: rusycystycznej, ukrainistycznej i białorutenistycznej. O realizowanej w KUL koncepcji studiów slawistycznych prof. Anna Woźniak pisała:

Ta symbioza, czyli obecność trzech filologii z gruntu „sowieckiego”, jak pewnie sądzili niektórzy, w tamtym czasie zdawała się ewenementem w programie uniwersytetu katolickiego, który legitymizował się jednoznacznym posłannictwem i ideałem służby „Deo et Patriae”. Był to bezsprzecznie projekt nowatorski, a usytuowanie go w ośrodku intelektualnym o formacji religijnej i teologicznej mogło wydawać się dziwne. Koncepcja Łużnego, łącząca wschodniosłowiańskie filologie $\mathrm{w}$ jeden organizm, okazał się zaskakująca także w skali ogólnopolskiej, gdzie do tej pory na różnych polskich uniwersytetach monopol przypadał filologii rosyjskiej, a dwie pozostałe, ukraińska i białoruska, funkcjonowały oddzielnie bądź nie było ich wcale. (Z trzydziestoletniej historii 180)

Warto dodać, że prof. R. Łużny kierował białorutenistycznymi pracami magisterskimi, a także prowadził w KUL wykłady i konwersatoria z zakresu literatury starobiałoruskiej i literatury XIX-wiecznej, podkreślając wielokrotnie wspólne źródła literatur wschodniosłowiańskich:

Dorobek kulturalny Rusi Kijowskiej jest wspólnym dobrem wszystkich Słowian wschodnich, dziedzictwem niezwykle cennym tych trzech narodów, które w wyniku skomplikowanych procesów historycznych, narodowościowych, kulturowych i językowych wyodrębniły się z pnia narodowości staroruskiej i które, słusznie odwołując się do wspólnej tradycji, na jej podstawie budowały swe własne narodowe piśmiennictwa - rosyjskie, ukraińskie i białoruskie. (Łużny 16)

Szczególna uwaga Profesora Łużnego była skoncentrowana na tych tekstach literatury starobiałoruskiej, które stanowiły przejaw życia duchowego Białorusinów: Żywot św. Eufrozyny Połockiej, kazania Cyryla Turowskiego, teksty poetyckie Symeona Połockiego (wł. Samuel Piotrowski-Sitnianowicz), Parenetica jednego do swej Rusi Hipacego Pocieja, przedmowy i posłowia do Biblii Franciszka Skaryny. W obszarze zainteresowań Profesora 
pozostawała także XIX-wieczna literatura anonimowa (postrzegana w aspekcie komparatystycznym).

Ze slawistyką KUL-owską na wiele lat związał swoje losy prof. Aleksander Barszczewski. Profesor Anna Woźniak, wieloletni dyrektor Instytutu Filologii Słowiańskiej KUL, tak oto ukazuje rolę prof. A. Barszczewskiego w rozwoju białorutenistyki KUL-owskiej:

Pierwsi studenci z grupy białoruskiej interesowali się kulturą białoruską, chłonęli jej literaturę, z zainteresowaniem i pilnie przykładali się do nauki języka białoruskiego. Owa atrakcyjność studiów białorutenistycznych była w tamtym czasie budująca i napawała nadzieją na przyszłość. [...] Nie byłoby bowiem warunków do rozwijania studiów nad językiem i literaturą białoruską w naszym uniwersytecie, ani też inicjowania, przynajmniej w początkowym stadium, prac badawczych i organizacyjnych $\mathrm{w}$ tym zakresie, gdyby nie ofiarna pomoc A. Barszczewskiego i jego wkład w formowanie postaw absolwentów białorutenistyki. (Profesor Aleksander Barszczewski 22-23)

Kadrę dydaktyczną nowego kierunku tworzyli także zaprzyjaźnieni wykładowcy z sąsiedniego uniwersytetu, czyli UMCS: prof. Teotyn Rott-Żebrowski, autor napisanych specjalnie na potrzeby studentów-białorutenistów skryptów językoznawczych: Gramatyka historyczna języka białoruskiego (1992) i Gramatyka języka białoruskiego (1992), prof. Michał Łesiów, prof. Michał Sajewicz oraz lektorzy języka białoruskiego - mgr Nina Sajewicz, autorka podręcznika akademickiego Materiały do praktycznej nauki języka białoruskiego (2000) i mgr Michał Kordas. O roli prof. Teotyna Rotta-Żebrowskiego w rozwoju białorutenistyki uniwersyteckiej Helena Głogowska pisała:

W latach koniunktury i zapotrzebowania na język białoruski w środowisku akademickim Lublina (1990-1997) slawista profesor Teotyn Rott-Żebrowski mógł służyć studentom, wykładając białoruską gramatykę opisową i historyczną. U schyłku swojej kariery naukowej przyczynił się do powstania białorutenistyki lubelskiej (na UMCS i KUL) i jako członek Międzynarodowej Asocjacji Białorutenistów stał się uznanym białorutenistą. (Białoruskie drogi profesora Teotyna Rott-Żebrowskiego 159

Z kolei prof. Michał Łesiów, dyrektor Instytutu Filologii Rosyjskiej i Słowiańskiej UMCS w okresie 1973-1976, Dziekan Wydziału Humanistycznego UMCS w latach 1981-1984, wybitny specjalista z zakresu onomastyki, historii języka i dialektologii, był wieloletnim kierownikiem Katedry Języków Słowiańskich KUL (do 1998 r.), promotorem prac magisterskich wielu 
językoznawców-białorutenistów, o czym niejednokrotnie wspominał prof. Michał Sajewicz:

Należy podkreślić, iż Profesor zawsze starał się przekazać swoim magistrantom solidną i szeroką wiedzę slawistyczną. Zachęcał rusycystów, zwłaszcza przed powołaniem w UMCS ukrainistyki i białorutenistyki, do podejmowania badań z zakresu językoznawstwa ukraińskiego i białoruskiego. Problematyce tej poświęcone były liczne prace magisterskie, które powstały pod kierunkiem Profesora w UMCS i innych uczelniach. (Prof. Michat Łesiów 32).

W wyniku nikłego zainteresowania polskiej młodzieży podejmowaniem studiów białorutenistycznych po kilku latach kierunek został zawieszony. Kontynuowane były jednakże badania naukowe nad literaturą białoruską najpierw w Katedrze Literatury Rosyjskiej, a od 2013 r. w Katedrze Literatury Ukraińskiej i Białoruskiej (od 1 października 2019 r. - Katedra Literatury Rosyjskiej, Ukraińskiej i Białoruskiej).

Dziś badania białorutenistyczne w tym ośrodku są prowadzone są przed dr hab. Beatę Siwek, autorkę dwóch monografii naukowych: Ojczyzna duża i mała. Poeci Białoruskiego Stowarzyszenia „Białowieża” wobec problematyki ojczyźnianej (2004) oraz Wolność ukrzyżowana. Rzecz o biatoruskim dramacie i teatrze (2011) i ponad siedemdziesięciu artykułów poświęconych nowej dramaturgii białoruskiej, twórczości poetów Białoruskiego Stowarzyszenia Literackiego „Białowieża”, twórczości prozatorskiej Iwana Ptasznikaua.

Imponująco przedstawiają się badania naukowe w zakresie języka, literatury i kultury białoruskiej prowadzone w drugim lubelskim ośrodku slawistycznym - Uniwersytecie Marii Curie-Skłodowskiej. W 1993 r. na wniosek Instytutu Filologii Słowiańskiej w Uniwersytecie Marii Curie-Skłodowskiej utworzono Pracownię Języka i Literatury Białoruskiej, działającą w latach 2005-2018 jako Zakład Białorutenistyki, a w latach 2018-2019 jako Zakład Białorutenistyki i Bułgarystyki, i uruchomiono pięcioletnie stacjonarne studia magisterskie na kierunku filologia białoruska. Z tym Zakładem byli związani badacze mający już spore osiągnięcia w badaniach białorutenistycznych: prof. Teotyn Rott-Żebrowski, prof. Michał Sajewicz (kierownik Zakładu przez cały okres jego istnienia) oraz prof. Siergiej Kowalow. Dydaktyka białorutenistyczna w UMCS uległa bardzo szybko przeformułowaniu. Ostatni rocznik filologii białoruskiej ukończył studia w roku akademickim 2004/05, a kształcenie białorutenistów odbywało się w ramach studiów slawistycznych (Sajewicz, Białorutenistyka w UMCS 493). Obecnie 
przedmioty białorutenistyczne weszły do programu studiów ukrainistycznych i rusycystycznych (m.in. Praktyczna nauka drugiego języka słowiańskiego - język białoruski, Rosyjskojęzyczna literatura Białorusi poza granicami Rosji, Białorusko-ukraińskie związki literackie).

Badania białorutenistyczne prowadzone w Uniwersytecie Marii Curie-Skłodowskiej dotyczą w głównej mierze gwar i antroponimii polsko-białorusko-ukraińskiego pogranicza językowego, białorusko-polskich związków literackich, kulturowych i językowych, wielojęzycznej literatury białoruskiej okresu Wielkiego Księstwa Litewskiego oraz współczesnej literatury białoruskiej, ze szczególnym uwzględnieniem białoruskiej dramaturgii. Efektem prowadzonych prac były dziesiątki artykułów publikowanych w polskich i zagranicznych periodykach naukowych oraz książkach wieloautorskich, prace zbiorowe, podręczniki i skrypty, a także autorskie monografie, m.in. prof. Michała Sajewicza, kierownika Zakładu Białorutenistyki w latach 2005-2019 ${ }^{4}$ - Nazwiska patronimiczne $z$ formantem -uk $w$ powiecie hajnowskim na Białostocczyźnie na tle ogólnopolskim (2013), prof. Siergieja Kowalowa, dyrektora Instytutu Filologii Słowiańskiej w latach 2017-2019, kierownika Katedry Literaturoznawstwa Słowiańskiego - Станаўленне польскамоўнай паэзіі ў полілінгвістычнай літаратуры Беларусі эпохі Рэнесансу (2002), Шматмоўная паэзія Вялікага Княства Літоўскага эпохі Рэнесансу (2010), Літаратура Вялікага Княства Літоўскага XVI пачатку XVII стст.: Феномен культурнага памежжа (2011), Пачвара у рэліктавым лесе. Літаратура. Тэатр. Крытыка (2013), dr hab. Jadwigi Kozłowskiej-Dody Панящие дом у сучаснай беларускай мове (2015), dr Agnieszki Goral Derywacja sufiksalna nazw subiektów czynności we współczesnym języku białoruskim. Dewerbalne i desubstantywne formacje agentywne (2013) oraz dr Natalii Rusieckiej Сямейная Муза. Паэзія Францішкі Уршулі Радзівіл (2007). Warto podkreślić, że prof. Siergiej Kowalow jest jednocześnie jednym z najbardziej znanych współczesnych białoruskich dramatopisarzy, autorem ponad trzydziestu tekstów dramatycznych, opublikowanych w zbiorach: Стомлены д'ябал (2004), Навука кахання (2004), Шлях да Бэтлеему: п'есы-казкі (2009), Сёстры Псіхеі (2011), Чатыры гісторыі Саламеі (2013), Крывічкі апокрыф (2013), a Natalia Rusiecka - poetką i znakomitą tłumaczką, autorką zbiorów poetyckich Два бяссонні (2004) і Каштаны у кішэнях (2015). Dr Agnieszka Goral, w artykule Badania kultury biatoruskiej w Instytucie Filologii

\footnotetext{
${ }^{4}$ Naukowym badaniom prof. M. Sajewicza poświęcony jest m.in. artykuł A. Goral Osobowe nomina agentis na Białostocczyźnie w badaniach profesora Michała Sajewicza.
} 
Słowiańskiej UMCS, tak oto podsumowuje działalność białorutenistyczną prowadzoną w rodzimym ośrodku:

Bogaty dorobek naukowy pracowników Zakładu Białorutenistyki IFS UMCS, liczba wypromowanych absolwentów, a także działalność popularyzatorska (promocyjna, przekładowa), oświatowa, kulturalna i integracyjna świadczą o dużym potencjale jednostki, która w ciągu dwudziestu lat zapewniła sobie ważne miejsce zarówno na UMCS, jak i na Lubelszczyźnie, a także w kraju. To dzięki staraniom kierownika i pracowników Zakładu lubelska uczelnia gościła znanych polskich i białoruskich pisarzy, myślicieli, działaczy społecznych, dramaturgów i twórców sztuki teatralnej, twórców sztuki ludowej (między innymi Sakrata Janowicza, Halinę Twaranowicz, Natalkę Babinę, Irynę Dorofiejczuk, Andreja Chadanowicza, Barysa Piatrowicza, Anatola Iwaszczankę, Walerego Jewarouskiego, Mikołaja Chalezina, Natalię Kaladę, Wolhę Baburynę, Wolhę Hapiejewą), ponadto dwukrotnie pracownicy i studenci Instytutu mieli zaszczyt osobiście poznać dorobek białorutenistów z Niemiec (prof. Gun-Britt Kohler z Oldenburga) oraz Litwy (prof. Lileja Plygavka $\mathrm{z}$ Wilna). Dwudziestoletnia pozanaukowa działalność pracowników Zakładu została utrwalona w licznych reportażach, relacjach prasowych, sprawozdaniach, wspomnieniach, wystawach, esejach publicystycznych i wywiadach, a także w liczącym ponad dwa tysiące zdjęć archiwum fotograficznym. (325-326)

Z inicjatywy pracowników Zakładu Białorutenistyki, we współpracy z pracownikami Zakładu Makrostruktur Społecznych Instytutu Socjologii UMCS, w 2007 r. rozpoczęto wydawanie rocznika Studia Białorutenistyczne (jej pierwszymi redaktorami byli Michał Sajewicz, Ryszard Radzik oraz Siergiej Kowalow), który po dziś dzień stanowi ważną platformę wymiany myśli naukowej polskich i zagranicznych białorutenistów, nie tylko literaturoznawców i językoznawców, ale też historyków, politologów, socjologów i kulturoznawców.

Z Zakładem Białorutenistyki UMCS aktywnie współpracował prof. Ryszard Radzik - socjolog, którego naukowe zainteresowania skupiają się na procesach narodowotwórczych na Białorusi, zagadnieniach tożsamości narodowej i etnicznej oraz problemach społecznych i kulturowych współczesnego społeczeństwa białoruskiego. Spośród licznych publikacji R. Radzika warto wymienić jego monografie Między zbiorowościa etniczna a wspólnota narodowa. Biatorusini na tle przemian narodowych $w$ Europie ŚrodkowoWschodniej XIX stulecia (2000), Kim sq Biatorusini? (2002), Zmiany struktury narodowościowej na pograniczu polsko-białoruskim $w X X$ wieku (2005), Вытокі сучаснай беларускасиі. Беларусы на фоне начыятворчых праџэсай у Цэнтральна-Усходняй Еўропе XIXст. (2012), Białorusini - 
między Wschodem a Zachodem (2012) oraz Вакол ідэнтычнасиі белаpycaỹ (2017).

Na białorutenistycznej mapie Polski ważne miejsce zajmuje Białystok. W 1997 r. w Uniwersytecie w Białymstoku powstała Katedra Kultury Białoruskiej, z którą związani byli przez wiele lat prof. E. Smułkowa - kierownik Katedry w latach 1997-2002, prof. Eugeniusz Mironowicz, historyk i działacz białoruskiej mniejszości w Polsce, autor monografii Białorusini w Polsce 1944-1949 (1993), Mniejszości narodowe w Polsce (1998), Historia państw świata XX wieku. Białoruś (1999), Białorusini i Ukraińcy w polityce obozu pitsudczykowskiego (2007), który kierował Katedrą do 2012 r., dr hab. Oleg Łatyszonek, historyk i działacz społeczny, autor prac Białoruskie formacje wojskowe 1917-1923 (1995), Od Rusinów Białych do Białorusinów. U źródet białoruskiej idei narodowej (2006), Наџьиянальнасиь - Беларус (2009), Гісторыя Беларусі ад сярэдзіны 18 cm. да пачатку 21 cm. (2013, wraz z E. Mironowiczem), dr hab. Helena Głogowska, autorka znakomitych monografii Białoruś 1914-1929: kultura pod presja polityki (1996), Białorusini na Wybrzeżu Gdańskim (2003), Stosunki polsko-biatoruskie w XX wieku: od Imperium Rosyjskiego do Unii Europejskiej (2012), Biatorusini w Polsce - mniejszość narodowa i imigranci (2013), dr hab. Irena Matus, autorka publikacji Szkolnictwo cerkiewno-parafialne $w$ powiecie bielskim w latach 1884-1914 na tle sytuacji oświatowej $w$ diecezji grodzieńskiej: $z$ dziejów oświaty ludu białoruskiego na Podlasiu (2006), Schytek unii i proces restytucji prawostawia $w$ obwodzie biatostockim $w$ latach 30. XIX wieku (2013) oraz dr Grażyna Charytoniuk-Michiej autorka licznych prac poświęconych zagadnieniu pogranicza polsko-białoruskiego, recepcji literatury białoruskiej w Polsce i polskiej na Białorusi, m.in. Literatura białoruska w Polsce: bibliografia przektadów za lata 1945-1994 (1996) oraz Obrzęd dziadów w dokumentach i w cyklu Mickiewicza (2011).

Po odejściu z Katedry historyków - prof. E. Mironowicza i dr hab. O. Łatyszonka - kierownictwo Katedry objęła prof. Lilia Citko. Na dorobek naukowy prof. L. Citko składają się trzy monografie: Nazewnictwo osobowe pótnocnego Podlasia w XVI wieku (2001), „Kronika Bychowca” na tle historii i geografii języka białoruskiego (2006), Piśmiennictwo i nazewnictwo starobiałoruskie na ziemiach Wielkiego Księstwa Litewskiego. Wybrane problemy (2019), dwie naukowe edycje tekstów źródłowych: Leksykon supraski z 1722 r. (2015), Białoruski Tristan: ze zbiorów Biblioteki Raczyńskich w Poznaniu (przekład i opracowanie, 2018) oraz ponad 80 artykułów poświęconych onomastyce pogranicza polsko-białorusko-litewskiego, 
leksykografii białoruskiej oraz świeckiej literaturze przekładowej okresu Wielkiego Księstwa Litewskiego. Jest ona także współautorką (wraz z Zofią Abramowicz i Leonardą Dacewicz) dwutomowego Stownika historycznych nazw osobowych Bialostocczyzny XV-XVII wieku (1997-1998).

W 2014 r., w związku z nieprzedłużeniem zatrudnienia dr hab. H. Głogowskiej, Katedra została zdegradowana do Zakładu Kultury Białoruskiej (kierownikiem została dr hab. I. Matus), który w roku akademickim 2019/20, w związku z reorganizacją struktur uczelnianych Uniwersytetu w Białymstoku w ramach nowej reformy, przestał funkcjonować.

Ważną inicjatywą Katedry Kultury Białoruskiej była organizacja interdyscyplinarnych konwersatoriów „Czwartki białoruskie”, w ramach których prezentowano wybrane problemy białorutenistyki.

Druga białostocka białorutenistyczna jednostka badawcza - Katedra Filologii Białoruskiej Uniwersytetu w Białymstoku została utworzona w listopadzie 1999 r. w Instytucie Filologii Wschodniosłowiańskiej. Jej kolejni kierownicy: prof. Michał Kondratiuk, sprawujący tę funkcję do 2004 r., absolwent białorutenistyki warszawskiej, badacz dialektów i specjalista w zakresie onomastyki Polski północno-wschodniej, autor tak znaczących publikacji, jak: Elementy battyckie $w$ toponimii i mikrotoponimii regionu białostockiego (1985), Urzędowe i gwarowe nazwy miejscowości Białostocczyzny (2011), Gwarowe nazwy miejscowości Białostocczyzny w układzie alfabetycznym (2014), Nazwy geograficzne i osobowe Białostocczyzny (2016), oraz dr hab. Halina Twaranowicz, znawczyni współczesnej literatury białoruskiej i twórczości literackiej poetów i pisarzy zrzeszonych w Białoruskim Stowarzyszeniu Literackim „Białowieża”, autorka licznych prac historycznoliterackich i komparatystycznych poświęconych literaturze białoruskiej oraz związkom literatury białoruskiej z literaturą polską i literaturami narodów byłej Jugosławii, m. in. Маральны свет героя: Беларуская і югаслаўская ваенная проза 60-70-х г2. (1986), Пакутаю здабыты мір: Тыпалогія характару ў беларускай і славенскай прозе (1991), Пад небам Айчыны. Літаратурна-крытычныя артыкульы (2005), Пры брамах Радзімы. Літаратурнае аб'яднанне “Белавежа": станаўленне, праблемы, асобы (2012), autorka zbiorków poetyckich Ускраек тысячагоддзя (1996), Верасы Дараганава (2000), Чацвёртая стража (2004), Бурштынавы яблькк (2010), wreszcie - tłumaczka poezji serbskiej i polskiej, wnieśli ogromny wkład w rozwój polskich badań nad językiem i kulturą Białorusi. Halina Twaranowicz poświęciła swoje liczne prace literaturoznawcze historii i działalności Białoruskiego Stowarzyszenia Literackiego „Białowieża”, 
analizie i interpretacji twórczości jego członków - Jana Czykwina, Jaszy Bursza, Janki Żamojcina, Uładzimira Hajduka, Michasia Szachowicza. Z Katedrą Filologii Białoruskiej UwB współpracował przez wiele lat prof. Jan Czykwin, historyk literatury rosyjskiej, białoruski poeta i działacz społeczny, autor białorutenistycznych monografii Далёкія і блізкія. Беларускія пісьменнікі замежжа (1997), Беларускія пісьменнікі Польшчы. Бібліяграфічны даведнік 1957-1998 (2000), Па прызванні і абавязку. Літаратурна-крытычныя артыкуль (2005), Ідэя, вобраз, інтэрпрэтаџыя (2014), wieloletni przewodniczący Białoruskiego Stowarzyszenia Literackiego „Białowieża”, wydawca periodyku Termopile i inicjator wydawnictwa „Biblioteczka Białowieży”, którego nakładem ukazało się już ponad sto publikacji książkowych, w tym także białorutenistycznych monografii naukowych. Historii Białoruskiego Stowarzyszenia Literackiego „Białowieża" są poświęcone m.in. monografie Teresy Zaniewskiej A dusza jest na Wschodzie: polsko-białoruskie zwiazki literackie (1993), Strażnicy pamięci. Poezja biatoruska w Polsce po roku 1956 (1997) oraz Anny Sakowicz Беларуская літаратура Польшчы: стылістычна-жанравыя асаблівасиі прозы “белавежиаў”, wydana w 2012 r. nakładem Wydawnictwa Uniwersytetu w Białymstoku.

Spośród bogatego dorobku pracowników Katedry Filologii Białoruskiej UwB warto także zwrócić uwagę na dwie monografie językoznawcze: Прыназоўнік у сістэме адной усходнеславянскай гаворкі Беласточчыны (2001) dr Bazylego Siegienia i Mikrotoponimia dawnego powiatu sokólskiego (2018) dr Aliny Filinowicz, a także dwie publikacje literaturoznawcze: Наиьлянальная ідэя у беларускай літаратуры ХІХ стагоддзя (2017) dr Joanny Wasiluk oraz Праблема ауттабіяграфізму у творчасиі Янкі Брыля (2017) dr Anny Alsztyniuk.

Należy przypomnieć jednak, że początki uniwersyteckiego kształcenia białorutenistycznego w Białymstoku sięgają 1992 r., kiedy to w białostockiej filii Uniwersytetu Warszawskiego utworzono Pracownię Białorutenistyki, która w 1996 r. została przekształcona w Zakład Białorutenistyki, a dopiero w 1999 we wspomnianą Katedrę Filologii Białoruskiej (Siegień 503). W 2000 r. miała miejsce pierwsza rekrutacja na kierunek filologia białoruska, który - niestety - kilka lat temu został zawieszony.

W Białymstoku ukazuje się ponadto kilka znaczących periodyków, publikujących wyniki najnowszych badań białorutenistycznych - Białorutenistyka Białostocka (red. H. Twaranowicz), Studia Wschodniostowiańskie (red. L. Dacewicz) oraz wspomniane już Termopile (red. J. Czykwin). Ponadto od 2001 r. 
w Krynkach na Białostocczyźnie wydawane jest wielojęzyczne pismo Annus Albaruthenicus, którego celem jest promowanie kultury i literatury białoruskiej wśród zachodnioeuropejskich czytelników. Jego założycielem i wieloletnim redaktorem był Sokrat Janowicz - białoruski pisarz, publicysta, działacz społeczny.

Obraz białorutenistycznych osiągnięć białostockich badaczy dopełniają prace historyków, politologów i kulturologów zrzeszonych w Białoruskim Towarzystwie Historycznym, które zainicjowało swoją działalność w 1993 r., a za cel postawiło sobie popularyzowanie historii Białorusinów, ze szczególnym uwzględnieniem pogranicza polsko-białoruskiego. Towarzystwo wydaje własny półrocznik - Białoruskie Zeszyty Historyczne, którego redaktorem naczelnym jest prof. Eugeniusz Mironowicz (dotychczas ukazały się 52 numery) oraz opublikowało wiele monografii (m.in. Ireny Matus Wieś StrzelceDawidowicze w tradycji historycznej; Wiesława Chorużego Białoruski drugi obieg w Polsce 1981-1990, o. Grzegorza Sosny i Doroteusza Fionika Cerkiew $w$ dziejach Bielska, Tomasza Błaszczaka Białorusini w Republice Litewskiej 1918-1940, Piotra Chomika, Heleny Głogowskiej i Sławomira Iwaniuka Historia Białorusinów Podlasia (2016)). O początkach działalności BTH Oleg Łatyszonek pisał:

Byliśmy młodzi i pełni zapału, więc Towarzystwo szybko rosło w siłę. Swoje czasopismo nazwaliśmy „Białoruskie Zeszyty Historyczne”, naturalnie na cześć Giedroyciowych „Zeszytów Historycznych”. Do Wsiewołoda Ihnatouskiego, patrona podziemnego wydawnictwa historycznego $\mathrm{z}$ lat 80 . doszli w naszym Panteonie podlaskich historyków wcześniejsi: Ignacy Daniłowicz, Michał Bobrowski i Józef Jaroszewicz. Na ogół, wykonaliśmy ogromną pracę, odtwarzając dzieje swojej społeczności. Dziś można śmiało powiedzieć, że nie ma na świecie takiej białoruskiej społeczności, której historia odtworzona byłaby $\mathrm{z}$ taką dokładnością jak dzieje Białorusinów na Białostocczyźnie. (7)

Ważną inicjatywą polskich białorutenistów jest organizowana cyklicznie konferencja, poświęcona polsko-białoruskim związkom kulturalnym, literackim i językowym. O jej znaczeniu tak piszą Agnieszka Goral i Dariusz Tarasiuk:

Tu spotykają się zarówno filolodzy, jak i historycy, socjolodzy, kulturoznawcy, muzykolodzy, etnografowie, religioznawcy z Polski, Białorusi i innych krajów europejskich. Wyniki swoich badań prezentują zarówno uznani, zasłużeni dla dialogu polsko-białoruskiego naukowcy, jak i badacze dopiero rozpoczynający karierę naukową. Zadaniem konferencji jest nie tylko rekonesans badawczy, ale 
także konsolidacja polskiego i białoruskiego środowiska slawistycznego oraz nakreślenie kierunków dalszej współpracy. Tradycją organizowanej od 1993 r. naprzemiennie w Polsce i na Białorusi konferencji z cyklu „Polsko-białoruskie związki kulturalne, literackie i językowe" jest życzliwa, sprzyjająca zwłaszcza młodym naukowcom, atmosfera oraz podejmowanie przez referentów dotąd niezbadanych lub mało opracowanych zagadnień badawczych. (369)

Zaprezentowany obraz białorutenistycznych osiągnięć to zaledwie część dokonań naukowych badaczy związanych z polskimi ośrodkami naukowymi i uniwersyteckimi. $Z$ uwagi na ograniczone ramy artykułu skoncentrowano się na wybranych faktach i zagadnieniach, zaprezentowano jedynie najważniejsze jednostki badawcze oraz ich naukowe osiągnięcia. Nie możemy jednak zapominać, że badania te były prowadzone (i często są kontynuowane) także w wielu innych ośrodkach naukowych, w ramach slawistycznych i rusycystycznych instytutów i katedr, m.in. w Instytucie Filologii Słowiańskiej Uniwersytetu Wrocławskiego (Franciszka Sielickiego Pieśni białoruskie i rosyjskie śpiewane na Wileńszczyźnie w okresie międzywojennym (1992), Białoruskie ludowe pieśni nabożne w zbiorach Pawta Szejna (1993); Telesfora Poźniaka Antologia poezji białoruskiej XX wieku (1997), Antologia literatury białoruskiej od XIX do poczatku XX wieku (1993), w Katedrze Językoznawstwa Słowiańskiego Uniwersytetu Warmińsko-Mazurskiego ${ }^{5}$ (prof. Alberta Bartoszewicza Stownik a tergo współczesnego języka białoruskiego (1988-89), Stownik białorusko-polski, polsko-białoruski (opracowany wraz z Teresą Jasińską, 1996), Aleksandra Kiklewicza Podstawowe struktury zdaniowe współczesnych języków stowiańskich: białoruski, bułgarski, polski (2910)), w Zakładzie Białorutenistyki i Ukrainistyki Uniwersytetu Opolskiego (Tomasza Wielga Poetyka prozy Wasyla Bykawa (2002)), w Katedrze Studiów Interkulturowych Europy Środkowo-Wschodniej Uniwersytetu Warszawskiego (Andrzeja Moskwina Teatr białoruski 1920-1930: odrodzenie i zagłada (2013), Literatury białoruskiej rodowody niepokorne (2019)), w Instytucie Neofilologii Uniwersytetu Zielonogórskiego (Bazylego Tichoniuka Odapelatywne nazwy terenowe Poludniowej Białostocczyzny (1986), Antroponimia potudniowej Białostocczyzny w XVI wieku (1988), Imiona i ich formy na pograniczu polsko-białoruskim od XVI wieku do roku 1839 (2000), Z badań nad wspótczesnymi językami wschodniosłowiańskimi i polskim (2001)) czy w Katedrze Kultury Słowian Wschodnich Uniwersytetu Jagiellońskiego (Dzimtryja Kliabanaua Krok po kroku. Poznajemy Białoruś. Język. Kultura. Krajoznawstwo, 2010).

\footnotetext{
${ }^{5}$ Do 1999 r. Wyższa Szkoła Pedagogiczna w Olsztynie.
} 
Osiągnięcia polskiej białorutenistyki są bezsprzeczne. Szczególnie mocno rozwinął się nurt badań językoznawczych, z powodzeniem realizowany w wielu akademickich ośrodkach uniwersyteckich. Nieco skromniej prezentują się osiągnięcia literaturoznawcze. Wciąż pozostaje wiele obszarów, kierunków i problemów, które dotychczas nie zostały poddane naukowemu oglądowi. Mam tu na uwadze, przede wszystkim, białoruską prozę historyczną i wojenną, białoruską prozę postmodernistyczną, białoruską literaturę autobiograficzną i pamiętnikarską, rosyjskojęzyczną literaturę Białorusi, zagadnienia postkolonializmu, postpamięci i traumy postkomunistycznej czy białoruskiej literatury emigracyjnej. Warto byłoby ponadto dopełnić prace historycznoliterackie refleksjami natury teoretycznej. Wciąż w niewystarczającym stopniu są zbadane takie zagadnienia, jak ewolucja gatunków literackich, koncepcje podmiotowości w literaturze białoruskiej czy przemiany współczesnych estetyk literackich.

Jaka będzie przyszłość polskiej białorutenistyki i jej miejsce we współczesnej nauce - trudno przewidzieć. Ostatnie wydarzenia polityczne na Białorusi, będące pokłosiem kolejnych wyborów prezydenckich, pozwalają mieć nadzieję na odrodzenie się białoruskiego języka i kultury, a tym samym na wzrost zainteresowania tym obszarem Słowiańszczyzny wschodniej. Czy te wydarzenia będą miały wpływ na odrodzenie się białorutenistycznych studiów uniwersyteckich i prowadzonych w nich badań naukowych? Za wcześnie, by odpowiedzieć pozytywnie na tak postawione pytanie. Kryzys studiów filologicznych ma bowiem głębsze podstawy. Jest on związany z pogłębiającym się od wielu lat niżem demograficznym, z konkurencją studiów o profilu praktycznym (taka tendencja zaznacza się w większości polskich i zagranicznych uniwersytetów), postępującym zmniejszaniem się zainteresowania studiami humanistycznymi czy też wreszcie ze statusem języka białoruskiego na Białorusi.

Pomimo tak znaczących osiągnięć polskich naukowców zajmujących się literaturą, kulturą, językiem i historią Białorusinów niepokoić może fakt luki generacyjnej, jaka coraz wyraźniej zarysowuje się na polskich uczelniach i w slawistycznych jednostkach badawczych. Zawieszenie lub - w niektórych przypadkach - zamknięcie studiów białorutenistycznych nie pozwala na kształcenie własnych kadr naukowych i dydaktycznych, a tym samym ogranicza rozwój naukowy dyscypliny. Pozostaje jedynie mieć nadzieję, że przyszłość przyniesie korzystne zmiany, a bogate osiągnięcia naukowe polskich białorutenistów będą stanowiły fundament kształtowania się nowych kierunków badawczych i stabilnego rozwoju dyscypliny. 


\section{BIBLIOGRAFIA}

50 lat slawistyki w Polskiej Akademii Nauk 1954-2004), red. Kwiryna Handke i in., Slawistyczny Ośrodek Wydawniczy, 2004.

Barszczewska, Nina. „Język białoruski w Polsce: historia i stan obecny”. Acta Polono-Ruthenica, nr 14, 2009, ss. 339-351.

Barszczewska, Nina. „Kulturowo-językowe dziedzictwo Podlasia - projekt badawczy Katedry Białorutenistyki Uniwersytetu Warszawskiego". Studia Białorutenistyczne, t. 10, 2016, ss. 263-278.

Charytoniuk-Michiej, Grażyna. „Literatura białoruska w Polsce po roku 1989. O potrzebie tworzenia bazy literackiej”. Studia z Filologii Polskiej i Stowiańskiej, nr 49, 2014, ss. 108-129.

Charytoniuk-Michiej, Grażyna. „Pogranicze w literaturze. Dokonania białostockiego środowiska naukowego". Bibliotekarz Podlaski, nr 4, 2017, ss. 249-271.

Droga ku wzajemności. Tom Jubileuszowy dedykowany Profesorowi Aleksandrowi Barszczewskiemu. Wydawnictwa Uniwersytetu Warszawskiego, 2006.

Drutski-Padbyareski, Balyaslaw. „Padruchny byelaruska-pol'ski-slownik” [Друцкі-Падбярэскі, Баляслаў. „Падручны беларуска-польскі слоўнік”], pawet.net/files/dp_slounik.pdf. Dostęp 24.11.2020

Głogowska, Helena. „Białoruskie drogi profesora Teotyna Rott-Żebrowskiego”. W stużbie nauki, wychowania $i$ wartości. Szkice biograficzne o lubelskim środowisku naukowym, red. Ryszard Skrzyniarz, Małgorzata Łobacz i Barbara Borowska, Episteme, 2015, ss. 121-160.

Głogowska, Helena. Białoruś 1914-1929: kultura pod presja polityki. Białoruskie Towarzystwo Historyczne, 1996.

Głogowska, Helena. „Stan badań nad historią Białorusi XX w. w Polsce”. Białoruskie Zeszyty Historyczne, nr 1(5), 1996, ss. 96-107.

Goral, Agnieszka. „Badania kultury białoruskiej w Instytucie Filologii Słowiańskiej UMCS w Lublinie". W stużbie nauki, wychowania i wartości. Szkice biograficzne o lubelskim środowisku naukowym, red. Ryszard Skrzyniarz, Małgorzata Łobacz i Barbara Borowska, Episteme, 2015, ss. 317-342.

Goral, Agnieszka. „Osobowe nomina agentis na Białostocczyźnie w badaniach profesora Michała Sajewicza". Zeszyty Cyrylo-Metodiańskie, t. 9, 2020, ss. 140-152.

Goral, Agnieszka, i Dariusz Tarasiuk. „Międzynarodowa Konferencja Naukowa Polsko-biatoruskie zwiazki kulturowe, literackie i językowe, Wisznice 22-24.06.2015”. Studia Biatorutenistyczne, $\mathrm{nr}$ 9, 2015, ss. 367-369.

Jackiewicz, Mieczysław. „«Szkoła białoruska» w polskiej literaturze romantycznej”. Acta Polono-Ruthenica, $\mathrm{nr}$ 1, 1996, ss. 113-121.

Kaleta, Radosław. „20. rocznica śmierci Profesor Antoniny Obrębskiej-Jabłońskiej (1901-1994) twórczyni i założycielki polskiej białorutenistyki”. Acta Albaruthenica, t. 14, 2014, ss. 391-393.

Kondratiuk, Michał. „O współpracy zespołu Pracowni Filologii Białoruskiej IS PAN z prof. Władysławem Kuraszkiewiczem w zakresie badania gwar”. Poznańskie Studia Polonistyczne. Seria Językoznawcza, t. 25 (45), nr 1, 2018, ss. 241-251.

Lewaszkiewicz, Tadeusz. „Zainteresowania białorutenistyczne Samuela Bogumiła Lindego”. Slavica - Onomastica - Regionalia. Prace dedykowane Panu Profesorowi Jerzemu Dumie, 
red. Maria Biolik i in., Wydawnictwo Uniwersytetu Warmińsko-Mazurskiego, 2016, ss. 97-106.

Łatyszonek, Oleg. „Słowo wstępne”. Tomczuk, Barbara. Białoruskie Towarzystwo Historyczne / Беларускае гістарычнае таварыства. Białoruskie Towarzystwo Historyczne, 2013, ss. 5-8.

Łużny, Ryszard. „Wstęp”. Literatura staroruska. Wiek XI-XVII. Antologia, oprac. Wiktor Jakubowski i Ryszard Łużny, Państwowe Wydawnictwo Naukowe, 1971.

Olechnowicz, Mścisław. Polscy badacze folkloru i języka białoruskiego w XIX wieku. Wydawnictwo Łódzkie, 1986.

Pankowicz, Andrzej. „Spór o genezę narodu białoruskiego. Perspektywa historyczna”. Krakowskie Studia Międzynarodowe, nr 4, 2004, ss. 89-106.

Sajewicz, Michał. „Białorutenistyka w UMCS w Lublinie”. Białorutenistyka Białostocka, t. 5, 2013, ss. 493-499.

Sajewicz, Michał. „Prof. Michał Łesiów (03.05.1928 - 15.07.2016). Uczony, który nosił w sercu dwie ojczyzny - Polskę i Ukrainę". Wiadomości Uniwersyteckie, nr 8/227, 2014, ss. 29-33.

Siegień, Bazyli. „Katedra Filologii Białoruskiej Uniwersytetu w Białymstoku - historia i stan obecny”. Biatorutenistyka Białostocka, t. 5, 2013, ss. 503-505.

Siwek, Beata. „Białoruska przestrzeń literacka i kulturowa w naukowej refleksji profesora Ryszarda Łużnego". Roczniki Humanistyczne, t. 61, z. 7, 2013, ss. 107-115.

Siwek, Beata. „Profesor Aleksander Barszczewski - uczony i poeta (W 90. rocznicę urodzin)”. Przeglad Wschodnioeuropejski, t. 11, 2020, ss. 209-218.

Smułkowa, Elżbieta. „Antonina Obrębska-Jabłońska (1901-1994)”. Elżbieta Smułkowa. Moje pogranicza $w$ historii, języku $i$ wspomnieniach. Slawistyczny Ośrodek Wydawniczy, 2016, ss. 271-290.

Srebrakowski, Aleksander. „Białoruś i Białorusini na Uniwersytecie Stefana Batorego”. Studia Slavica et Balcanica Petropolitana, nr 2(10), 2016, ss. 79-94.

Stochel, Włodzimierz. „Białorutenistyczne eksploracje Bazylego Białokozowicza”. Acta PolonoRuthenica, nr 6, 2006, ss. 49-57.

„Światta masz tyle $w$ sobie...” Ze studiów wschodniostowiańskich. Księga pamiątkowa dedykowana Profesorowi Aleksandrowi Barszczewskiemu w osiemdziesiata piata rocznice urodzin, red. Marta Kaczmarczyk, Albert Nowacki, Monika Sidor i Beata Siwek, Wydawnictwo KUL, 2015.

Timoszuk, Mikołaj. „Księga Rodzaju w przekładach na współczesny język białoruski”. Acta Albaruthenica, t. 14, 2014, ss. 243-255.

Timoszuk, Mikołaj. „O języku białoruskich przekładów Ewangelii w Ameryce Północnej”. Acta Albaruthenica, t. 13, 2013, ss. 199-217.

Timoszuk, Mikołaj. „Współczesne białoruskie słownictwo sakralne w przekładach Pisma Świętego". Studia Biatorutenistyczne, t. 4, 2010, ss. 275-282.

Tvaranovich, Halina. Pad nyebam Aychyny. Litaraturna-krytychnyya artykuly. Wydawnictwo Uniwersytetu w Białymstoku, 2005 [Тварановіч, Галіна. Пад небам Айчыны. Літаратурна-крытычныя артыккуль. Wydawnictwo Uniwersytetu w Białymstoku, 2005].

Tvaranovich, Halina. Pry bramakh Radzimy. Litaraturnaye ab'yadnannye "Byelavyezha": stanawlyennye, prablyemy, asoby. Wydawnictwo Uniwersytetu w Białymstoku, 2012 [Тварановіч, Галіна. Пры брамах Радзімы. Літаратурнае аб'яднанне “Белавежа": станаўленне, праблемы, асобы. Wydawnictwo Uniwersytetu w Białymstoku, 2012]. 
Woźniak, Anna. „Profesor Aleksander Barszczewski i jego związki z Katolickim Uniwersytetem Lubelskim. Na Jubileusz 75-lecia”. Roczniki Humanistyczne, t. 53, z. 7, 2005, ss. 21-25.

Woźniak, Anna. „Profesor Ryszard Łużny (1927-1998)”. Ryszard Łużny. Myśl stowiańska Jana Pawła II. Zbiór artykułów, red. Jan Orłowski i Anna Woźniak, Wydawnictwo KUL, 2015, ss. 11-14.

Woźniak, Anna. „Z trzydziestoletniej historii Instytutu Filologii Słowiańskiej w Katolickim Uniwersytecie Lubelskim Jana Pawła II”. Roczniki Humanistyczne, t. 68, z. 7, 2020, ss. 175-196.

\section{BIALORUTENISTYKA POLSKA: \\ HISTORIA - STAN OBECNY - PERSPEKTYWY ROZWOJU}

Streszczenie

$\mathrm{W}$ artykule przedstawiono historię polskich badań nad językiem, literaturą, kulturą i historią Białorusinów, a także przybliżono działalność najważniejszych ośrodków uniwersyteckich, w których prowadzone były, począwszy od 1956 r., studia białorutenistyczne: Katedry Białorutenistyki Uniwersytetu Warszawskiego, Katedry Filologii Białoruskiej oraz Katedry Kultury Białoruskiej Uniwersytetu w Białymstoku, Zakładu Białorutenistyki Uniwersytetu Marii CurieSkłodowskiej oraz Instytutu Filologii Słowiańskiej Katolickiego Uniwersytetu Lubelskiego Jana Pawła II. Zarysowano ponadto najważniejsze kierunki aktualnie prowadzonych badań naukowych oraz zarysowano perspektywy rozwoju naukowej białorutenistycznej refleksji językoznawczej i literaturoznawczej. Szczególną uwagę zwrócono na publikacje monograficzne i prace dokumentacyjne prowadzone przez polskich badaczy-slawistów, które miały najistotniejszy wpływ na kształtowanie się i rozwój współczesnej refleksji białorutenistycznej w Polsce.

Slowa kluczowe: literaturoznawstwo; językoznawstwo; historia; badania naukowe; studia filologiczne; Białoruś.

\section{POLISH BELARUSIAN STUDIES: HISTORY, CURRENT STATE AND PROSPECTS FOR DEVELOPMENT}

\section{Su m m ary}

This article traces the history of Polish research on the language, literature, culture and history of the Belarusians. It also looks at the activities of the most important university centres where, since 1956, Belarusian studies have been conducted: the Department of Belarusian Studies at the University of Warsaw, the Department of Belarusian Philology and the Department of Belarusian Culture at the University of Bialystok, the Faculty of Belarusian Studies at the Maria Curie-Sklodowska University, as well as the Institute of Slavic Philology at the John Paul II Catholic University of Lublin. This work not only depicts the most significant areas of current research, but also presents the prospects of the development of academic Belarusian linguistics and literary reflection. Particular attention is paid to those monographs and documentary publications led by Polish researchers which have had the most influence on the development and progress of contemporary Belarusian studies in Poland.

Keywords: literary studies; linguistics; history; academic research; philological studies; Belarus. 